\title{
South Africa's domestic intermodal imperative
}

Jan Havenga, Zane Simpson, Anneke de Bod

Department of Logistics, Stellenbosch University, South Africa

\begin{abstract}
An integrated alternative to road only or rail only transport does not exist in South Africa for domestic freight. This is in spite of the fact that national freight logistics costs are high, road infrastructure is challenged and concern for the environmental impact of road transport is increasing. These factors have renewed interest in intermodal transport solutions, which are the focus of this article. The question is whether a viable domestic intermodal solution can be found through segmenting freight flows and developing a business case based on these segments. The research confirms that this is possible and the segmentation and subsequent business case is presented. The results demonstrate that building three intermodal terminals to connect the three major industrial hubs - Gauteng, Durban and Cape Town through an intermodal solution could reduce transport costs (including externalities) for the identified 22.9 million tons of intermodal freight flows on the Cape and the Natal corridors by $64 \%$ (including externalities).
\end{abstract}

Keywords: Transport costs; Intermodal; Modal shift

\section{Introduction}

The history of global maritime container transportation is well known and its development over the last 50 years was well documented. It is also one of the drivers of domestic intermodal transport. For example, APL (USA) saw it as an alternative to shipping empty international containers back to the West Coast (Peach, 1992).

De Witt and Clinger (1999:1) provide a definition of intermodal transport in simple terms as the 'use of two or more modes to move a shipment from origin to destination', but Jannic and Reggiani's (2001:471) addition of "goods in the same loading unit or vehicle and the absence of goods handling in transhipment" is important. The European Commission's description of a "characteristic of a transport system that allows at least two different modes to be used in an integrated manner in a 'door-to-door' transport chain and that it is a quality indicator of the level of integration between different transport modes" (European Commission, 1997:1) is even more helpful. Nemoto, Browne, Visser, and Castro (2005) add the word 'seamless' to the door-to-door concept, and describe technologies, such as 'swap bodies' which, despite their suitability, are absent from the South African system.

Containers, often known as intermodal containers or ISO (International Organisation for Standardisation) containers, are the main type (but not exclusively so) of equipment used in intermodal transport, particularly when one of the modes of transportation is shipping. In South Africa, use of the term 'container' in freight shipping has become synonymous with this standard, and the use of this equipment is synonymous with 'intermodal transport'. None of the other possible forms of intermodal transport (such as roadrailers, piggybacking or swap bodies) are very familiar or used in this country.

When domestic intermodal freight transport in South Africa is discussed, road and rail freight transport are in play (South Africa has no inland waterways that can be navigated). 
Although not widely known in a domestic context, intermodal solutions for local transport have been proposed by some researchers as a key element to addressing South Africa's freight logistics challenges (DoT (National Department of Transport, South Africa), 1998, DoT (National Department of Transport, South Africa), 2005, Havenga et al., 2009 and Van Eeden and Havenga, 2010). This is seen as a solution for South Africa to exploit economies of density and size, increasing rural access and reducing logistics costs.

The political and corporate will to develop domestic intermodal solutions does exist, and a high-level business case should support the feasibility of such a solution. Stakeholders should be challenged to take the initiative, and set aside myopic interests and paradigms based on the past in order to address this challenge. As with the development of key national roads projects (McKenzie, 2011b and McKenzie, 2011a) and bulk export rail expansions (Creamer, 2011), the establishment, fast tracking and collaborative funding of a domestic intermodal freight programme must be a macroeconomic priority. The research should indicate new and innovative ways in which supply chains can collaborate to achieve cost savings and make South Africa more competitive in the global marketplace. The paradigm of competing on the ability of companies to improve supply chain behaviour should sometimes shift to a meso-level focus, as indicated by Demkes and Tavasszy (2000) (see Fig. 1).

In the sense that transport is often seen as an administered cost due to the fact that a large portion is dependent on the fuel price and cannot be influenced at a company level, mesolevel solutions that optimise economies of scale amongst industries and within society could benefit entire industries and lead to welfare improvement. Sommar and Woxenius (2007) add tax, congestion and environmental concerns as reasons why sustainable transport solutions are a priority in Europe. These, together with the fuel price are all administered costs and reasons why nationwide solutions should be considered would transcend firmlevel analysis.

The current body of knowledge in the logistics discipline often has a firm level approach to intermodal solutions, often focusses on maritime based or international intermodal freight and have little applications in sparsely inhabited countries with long densified corridors. Rail suitable cargo is often identified colloquially and without proper segmentation principles in mind. This situation could be improved by freight flow segmentation that enables a business case for specific segments. The research question and objective of this article are therefore to determine if the measuring methodology for a domestic intermodal business case can be identified and then be applied to South Africa's total freight flow situation as a case study.

The research methodology followed to achieve this objective is described in the next section.

\section{Research methodology}

Observations of the development of intermodal freight and then specifically domestic intermodal solutions and its relevance to the South African situation create the initial platform for the research. A first approach to determine the target market for domestic intermodal solutions in South Africa was proposed by Van Eeden and Havenga (2010), who identified intermodal-friendly flows based on uniform, dense freight flows on long-distance corridors, derived from South Africa's Freight Demand Model (Havenga, 2007, Havenga, 2010 and Havenga and Pienaar, 2012). 
It is, however, necessary to describe the proverbial "burning platform" for the problem in South Africa, i.e., the specific spatial challenges which are unique and different from Europe and The USA, which is the first step of this research. This is followed by flow segmentation based on South Africa's Freight Demand Model (FDM) ${ }^{1}$. Subsequent to this analysis, more in-depth research and stakeholder consultations were conducted to develop background to a high-level business case for intermodal-friendly traffic. ${ }^{2}$ The research was also expanded to quantify the potential cost savings of an intermodal versus a road-only solution for the identified traffic. In addition, the potential impact of a domestic intermodal solution on externality costs and $\mathrm{CO}_{2}$ emissions was also analysed. This subsequent research methodology is much more detailed and robust than the initial 2010 research, reflecting on the deeper analysis and segmentation principles required to initiate the process of building a business case for domestic intermodal.

The cost of road freight transport was obtained from South Africa's national logistics cost model. The logistics cost model research approach and 2008 results of the model's application are detailed in Havenga (2010), and the 2009 results published in Havenga, Pienaar, and Simpson (2011). The calculation of road transport costs is driven by weight in tons and distance travelled, and involves the summation of all the different cost elements of road transport on a specific route (including items such as licence and toll fees). The different cost elements of road transport are determined by the vehicle type, which in turn is determined by the commodity type, network typology (i.e., whether it travels on corridors, in rural areas, or in metropoles) and route of travel.

To determine the current transport cost of palletisable freight, the total weighted cost of these flows between distribution centres was calculated. This was translated into cents per tonkm data and compared to the current actual cents per tonkm data for similar freight received from the national railroad. The potential cost savings experienced on rail due to the introduction of an intermodal solution can be attributed to an increase in a more favourable relationship between fixed and variable costs where more freight is available to absorb fixed costs (commonly called an improvement in density). This relationship was first researched by Harris (1977) and depicted in Fig. 2.

Externality costs include all non-charged costs, which include emissions, accidents, congestion, policing and noise pollution. Total road and rail freight externality costs were calculated for the first time in South Africa's sixth annual state of logistics survey (Havenga et al., 2009), and refined in the seventh survey (Havenga et al., 2010).

\footnotetext{
1 Data sourced from the Freight Demand Model (FDM) for South Africa. The methodology was developed between 1995 and 2007 , described in Havenga (2007) and published in Havenga (2010) and Havenga and Pienaar (2012). It is currently accepted as the only reliable Freight Transport Demand database in South Africa and used for the planning of all large national logistics infrastructure projects, such as the development of rail and port facilities.

2 Industry consultation included organised logistics service providers such as the Federation of Supply Chain Management and the Road Freight Association, freight owner organisations such as the Consumer Goods Council of South Africa, the National Association of Automobile Manufacturers of South Africa, the Shippers Council, the Automotive Industry Development Corporation and the Exporters Club of South Africa and finally various professional practitioner bodies such as the Chartered Institute for Purchasing and Supply, the Association of Operations Management of South Africa, the Supply Chain Council and the Transport Forum.
} 
Externality costs are calculated to depict the actual cost to the environment in monetary terms. Externality costs, with the exception of emissions, are based on a study done by Jorgensen (2009). Jorgensen (2009) calculated accident costs based on a 2006 survey on the N3 highway between Johannesburg and Durban, congestion costs based on studies conducted in Australia and Europe, and noise and policing costs based on Australian research.

Emission externality costs are determined by calculating emission generation per tonkm per mode. For road, fuel consumption is the critical variable when calculating the amount of $\mathrm{CO}_{2}$ emissions per tonkm. For rail, a weighted combination of diesel and electricity consumption is used to determine this. With regard to the intermodal solution's emissions, the same approach as that previously stated is used but only for the intermodal-friendly freight. This is possible as the emissions calculated are mode specific and are calculated at a tonkm level. Savings are calculated as the amount of emissions not being produced by road freight due to the switching of all the potential intermodal freights to rail.

South Africa's National Treasury is seeking to implement a carbon tax to reduce greenhouse gas emissions (SA National Treasury, 2010). A tax of R75 per ton (in 2005 terms) of $\mathrm{CO}_{2}$ is proposed, increasing to around R200 per ton (in 2005 terms) of $\mathrm{CO}_{2}$ (the time frame is not clear from the National Treasury discussion document). In this article, the potential reduction in tonnage of $\mathrm{CO}_{2}$ emitted is demonstrated through an $\mathrm{R} 165$ per ton of $\mathrm{CO}_{2}$ tax (this was the value used by the National Treasury in their feasibility studies) (SA National Treasury, 2010). Calculating the amount of $\mathrm{CO}_{2}$ tax savings that could be achieved by using an intermodal solution to transport freight was determined by using the emission savings calculated and multiplying this with the tax rate of R165 per ton of $\mathrm{CO}_{2}$.

\section{Intermodal freight transport in the USA and Europe}

Intermodal rail transport is the fastest-growing rail traffic segment in the USA; it increased from 3 million trailers and containers in 1980 to 11 million in 2010 (a compound annual growth rate of 5\%). Most intermodal rail traffic consists of consumer goods, approximately $40 \%$ of which are contributed by domestic intermodal rail traffic, reflecting on the vital role that railroads play in the domestic economy (Association of American Railroads, 2011). Case (2009:5) states that intermodal traffic is 'holding its position [in the USA] in a falling transportation market' and that this is proof that 'such services are now structurally integrated in the transportation market'.

In Europe (OECD member countries), the number of TEUs on rail tripled between 1980 and 2008 to 16 million (a compound annual growth rate of 4\%) (OECD, 2010). Intermodal traffic in the USA surpassed coal traffic as far back as 2003, and is projected to be the rail's best hope of recovery after the recession (Kolstad, 2009). Woodburn (2008) also cites the decline in 'traditional' rail transport industries and the concurrent development of consumer goods markets as a driver of the substantial intermodal freight growth in the UK.

Nemoto et al. (2005:18) refer to short-distance intermodal transport as a solution to environmental concerns in waste management, especially in cities. They specifically request the selection and assembly of 'data on a few global logistics indicators for monitoring and benchmarking, focusing on key features of intermodal logistics' and state that 'in particular, the impacts and effectiveness of short-distance intermodal systems have not been 
completely recognised, and thus, it is important to ascertain assessment criteria by using these indicators'.

Yevdokimov (2000) provides an extensive analysis of intermodal's advantages in the USA and echoes Berwick's (2001) regional findings (mentioned in the Introduction section) on a macroeconomic scale, i.e., increased volumes on the transport network, resulting in economies of density, expansion of the network and resultant economies of size, reduction in logistics, and increased access to input and output markets. The European Intermodal Research Advisory Council (EIRAC, 2005) confirms that intermodal transport will enable Europe to cope with increasing transport demands, improve the environmental impact of transport, and enhance its competitiveness.

These advantages are better understood if intermodal transport is regarded as a general purpose technology (GPT), which is typically characterised by statistically significant spillover effects to other areas of the economy (Laaksonen, 1999 and Yevdokimov, 2000).

Yevdokimov (2000) states that intermodal transport is viewed as a two-way improvement of economic productivity by improving both the current operational functions of the system and expanding them. He demonstrates that a once-off $10 \%$ increase both in the frequency of transport and transport network expansion due to intermodal transport resulted in a permanent increase in annual economic growth, gradually increasing and reaching a peak of $3 \%$ per annum after 15 years and then settling over the long term at a $0.4 \%$ increase in economic growth per annum. The GPT nature of intermodal transport is also alluded to by Brown and Hatch (2002:5), who suggest that this 'may be the most efficient and socially beneficial means of providing freight capacity'.

Positive environmental effects were not included in Yevdokimov's analysis (2000). The addition of this factor to future models should further illustrate the positive spin-offs from intermodal transport. In Europe, for example, rail/road intermodal solutions have reduced $\mathrm{CO}_{2}$ emissions by $55 \%$ (or by 1.8 million tons per year) and saved $29 \%$ of energy usage compared to a road-only solution, with an estimated annual environmental savings of about $€ 180$ million (European Commission, 2008). According to the Association of American Railroads (2011) (The Association), railroads are, on average, four times more fuel efficient than trucks, with 7 gal of fuel required to haul 1 ton of freight coast-to-coast in America via rail, compared with 28 gal via road. This has resulted in railroads, while almost doubling their freight volumes between 1980 and 2010, by using virtually the same amount of fuel as in 1980 . The Association states that shifting $10 \%$ of long-distance road freight to rail would save more than a billion gallons of fuel per year, and annual greenhouse gas emissions would fall by more than 12 million tons.

\section{The growth of domestic intermodal solutions}

Woodburn (2008) describes the origins of intermodal transport in the UK, which was the moving of domestic freight only. The emergence of deep-sea container freight changed that and the focus shifted to deep-sea freight. It is regrettable that South Africa, with long dense transport flows of domestic freight, which is even much more suited for domestic intermodal solutions, followed this trend. The development of intermodal transport technology in South Africa has kept pace with the demands of shipping lines, but developments in domestic intermodal service technology such as the swap bodies that Woodburn refers to have been neglected. 
According to De Witt and Clinger (1999:2), domestic intermodal services are 'a significant and critical factor in the execution of supply chains'. Peetermans and Sellnick (2010) confirm that in Europe there is a growing trend towards companies delivering both domestic and international services - the number of companies providing both services has increased from $45 \%$ to $57 \%$ of the total number of intermodal service providers between 2005 and 2009 , and their TEU (20-foot equivalent unit) weighted market share has increased from $68 \%$ to $80 \%$. Over the same period, intermodal operators providing only domestic services have, on average, grown their businesses, but the opposite has occurred with companies providing only cross-border intermodal services.

Woodburn and Piotrowska (2012) report that 'domestic intermodal' as defined in a published data includes the domestic rail transport of maritime freight. Woodburn however, recently, was able to identify the real domestic intermodal submarket by analysing the rail freight database and reports a fivefold increase in weekly services between 1998 and 2011 (Woodburn, 2012). He reports growth in domestic intermodal services as a whole in the UK as far outstripping growth in any other commodity group and the potential for rail growth as 'very considerable' (2012). Rodrigue and Browne (2008) include both land and maritime intermodal strategies for the control of distribution channels.

A regional study carried out in North Dakota (USA) by Berwick (2001) demonstrated the benefits of domestic intermodal transport. These included a reduction in overall transport costs, an increase in economic productivity, a reduced burden on highway infrastructure, higher returns from public and private infrastructure investments, reduced energy consumption, and increased safety. Brown and Hatch (2002) highlight the potential for intermodal freight transport to become the core of America's long-distance freight transport market, and even foresee a role for intermodal in middle- and short-distance markets. Strong growth in domestic intermodal freight is also reported for other countries, such as Italy and Germany (Silborn, 2008), which is significant as Germany holds a dominant position (almost half) in the European domestic intermodal market (Woxenius \& Bärthel, 2008). One of the key driving forces behind this growth in intermodal freight transport is that intermodality allows each transport mode to utilise its core strength in building supply chains that are, on the whole, more efficient, cost effective and sustainable. In comparison to the UK, with shorter average transport distances, i.e., $201 \mathrm{~km}$ for rail (Woodburn \& Whiteing, 2010), Germany (and in a larger context Europe) has long transport distances, making the additional charges of freight consolidation and terminal handling an attractive option when total costs are compared. A large volume of South Africa's freight on corridors travels much further than freight in Europe, with an average transport distance of $320 \mathrm{~km}$ for all freight and $550 \mathrm{~km}$ for rail freight (FDM).

The European Union's confidence in an optimal balance between road and rail freight transport is evidenced by its budget of $€ 450$ million for the period 2007-2013 for the Marco Polo programme. New projects that shift freight from road to rail, sea or inland waterways are co-funded during the start-up phase before the projects become profitable. The programme aims to free Europe's roads of an annual volume of 20 billion ton-kilometres (tonkm) of freight, which is the equivalent of more than 700000 trucks a year travelling between Paris and Berlin (European Commission, 2011). Woxenius' research (2007) into transport network designs to support intermodal solutions is premised on the European policy maker's belief that intermodality could solve many problems related to all-road freight transport. 
South African policymakers have likewise expressed the desire for a modal shift and a domestic intermodal solution (DoT (National Department of Transport, South Africa), 2005 and DoT (National Department of Transport, South Africa), 2011; The Presidency, 2011). Private partners have also expressed an interest in participating in such a solution through both direct investment (Naidoo, 2011) and cooperation by using licenced technology such as RoadRailer (Grove, 2005). In fact, as far back as 1995, in a survey conducted by Havenga (1995), 70\% of 46 road hauliers indicated a willingness to explore piggybacking further with the railway. The road hauliers believed that the service would be of benefit to insurance companies due to lower claims, reduce road maintenance expenditure and save transport costs; and that a joint venture with the railways could benefit all parties. The respondents were asked to provide numbers of specific trailers that they were willing to ring-fence and commit to a service, and 1298 trailers were identified.

However, four years later, Jorgensen (1999:1) reports that 'this potential, already successfully implemented in the Americas, Europe and Australasia, has unfortunately not been realised in Southern Africa'. A contributing factor is that, in order to enable this shift, freight flows that exploit the core strengths of both rail and road must be identified, yet the case for domestic intermodal solutions has never been clearly and unequivocally made. The research presented in this article aims to rectify this situation.

In the next section South Africa's logistics risk factors are defined to highlight the proverbial "burning platform" that leads to the conclusion that a more efficient transport supply would be beneficial for this country specifically.

\section{South Africa's logistics risk factors}

The only long term (30 years) measurement of national logistics costs in the world is the work of Wilson (2010) for the USA. South Africa introduced a measurement system in 2003 (Havenga, 2010) and eight annual measures have been completed. Certain pertinent longterm trends, however, can be gleaned from the USA study. Logistics costs as a percentage of GDP have declined in the USA over the last three decades (Wilson, 2010). This was achieved by better inventory management, resulting in lower inventory-carrying costs. Freight transportation's share of logistics costs is increasing as a direct result of the relentless reduction in inventories. This must be seen in the light of the reduction in transportation costs to increase competitiveness and moving higher on the agenda of developed and developing countries alike (see, for example, the cases of the USA in Wilson, 2010; Brazil in World Bank, 2010; Latin American and Caribbean countries in Schwartz, Guasch, \& Wilmsmeier, 2009; and South Africa in Havenga, 2010).

Most supply chains in mature economies have by now achieved high levels of efficiency and requiring tighter inventory control. The latter is often seen as one of the last areas of competitive advantage (Grant, Lambert, Stock, \& Ellram, 2006), as inventory is often the largest single investment in assets for most manufacturers, wholesalers and retailers (Stock \& Lambert, 2001). Tighter inventory control, however, has a trade-off: greater demands on the transport function (Jammernegg \& Reiner, 2007). Growth in specialisation - for example, by the pull phenomenon of consumer power and production offshoring (Wisner, Leong, \& Tan, 2005) - has led to increasingly elongated supply chains, further escalating transport costs. This is evidenced by the growing proportion of GDP dependent on international trade. In 1950, only 5\% of the US GDP was generated from trade, compared to $25 \%$ by 2011 (World Bank, 2012). Similarly, global trade grew exponentially, from $10 \%$ of 
global GDP in the 1970s to one-third by the turn of the century - and it will soon approach half of the global GDP (Havenga, 2011).

Elongating supply chains were historically economically tolerable due to the low price of oil and the absence of total-impact accounting. The exogenous forces impacting on transport are, however, expected to deteriorate due to the increasingly negative outlook for the oil price on the one hand, and the imminent inclusion of at least some externality costs in transport costs on the other.

Oil is regarded as 'the most important raw material in world trade, whose ample availability is a crucial precondition for keeping the world's transport system rolling' (Radetzki, 2002:1). It supplies more than $90 \%$ of the energy for world transportation (Fantazzini, Höök, \& Angelantoni, 2011). Freight transport, in turn, accounts for $40 \%$, on average, of a company's total logistics costs (McKinnon, 2009) and a similar percentage of global logistics costs (Roberts, 2003).

In addition to the cost risk posed by higher oil prices, the imposition of environmental taxes will further inflate the real cost of carbon-intensive transport (McKinnon, 2009), thereby leading either to a reduction in the demand for energy or switching from more to less carbon-intensive fuels (Winkler \& Marquard, 2011). Piecyk and McKinnon (2007) conducted a study to determine the degree to which road freight externality costs (i.e., infrastructural, environmental and congestion costs) are internalised through taxation in the UK.

Approximately two-thirds of freight tonnage transported in the UK is conveyed by road, leading to $f 7.1$ billion in externality costs to the economy (2006 base case scenario). The taxes paid by heavy goods vehicles accounted for approximately two-thirds of these costs. The authors suggest that taxes on heavy vehicles would have to increase by around $50 \%$ to fully internalise these externality costs (although it will have competitive impacts given the open EU road transport market).

The dubious 'upside' of these two challenges is that actions to address them are mutually inclusive - economically effective business strategies that improve the transportation bottom line correspond with environmentally friendly logistics strategies by reducing the carbon footprint. Similarly, strategies that focus on reducing carbon emissions typically improve transportation efficiency (Simchi-Levi, 2011). In South Africa, it is hypothesised that one of the most important strategies in this regard is domestic intermodal solutions.

When expressing ton-kilometre requirements in terms of GDP (i.e., how much is contributed to the GDP by moving a ton of freight $1 \mathrm{~km}$ ), as depicted in Fig. 3, South Africa emerges as a highly 'transport-hungry' country compared with the rest of the world, especially Western Europe. The transport-hungry nature of South Africa, combined with the fact that the key driver of transport cost is a commodity with a volatile pricing structure, indicates that transport is, in fact, a strategic resource requiring national attention. In this context, overarching strategies that contribute to the lowering of transport costs on a national level are of the utmost importance.

South Africa's "transport-hungry" nature is caused by a demand side problem (spatial challenges) and supply side problem (inordinate reliance on road freight that could be on rail, which is the focus of this article). The spatial challenges are illustrated in Fig. 4, depicting total freight flows in South Africa (the thickness of each line is relative to the volume of freight). The figure to the left depicts all freight flows and the figure to the right 
shows all flows with two "export machines", essentially coal and iron ore "conveyor belts", removed.

The major long distance flows are between Gauteng and Cape Town (distance $1400 \mathrm{~km}$ ) and between Gauteng and Durban (distance $570 \mathrm{~km}$ ). The industrial centre in the heartland (caused by the discovery of gold and diamonds in the 1880s) is the obvious demand side problem and the major difference between South Africa and comparable economies such as Brazil and Australia. The long thick corridors with little industrial activity in between are also the major difference between the country and Europe.

South Africa's freight logistics bill for 2010 was R339 billion and, while it is $4.9 \%$ higher than the R323 billion in 2009, is an improvement from $13.5 \%$ to $12.7 \%$ of the GDP (Simpson \& Havenga, 2011). However, a more detailed analysis of logistics cost elements as depicted in Fig. 5 reveals the transportation problem.

The recent marked decline in inventory carrying cost is to be expected in the face of the prime rate that is currently at its lowest point since 1974 . There has, however, been a sharp increase in transport costs, and it is this juxtaposition that is a serious point of concern.

In summary, South Africa's major future risks are an over reliance on fuel driven road transport on the supply side and demand side challenges caused by a relentless drive to lower inventories. Both these national risks can be alleviated by an integrated demand side approach on industry level (where the relationship between inventory and transport can be better managed) and domestic intermodal supply side solutions.

In the next section the transportation problem is analysed in more detail through freightflow segmentation, followed by an analysis to determine whether a natural intermodal opportunity that can be exploited could be identified.

\section{Freight-flow segmentation}

In order to understand the underlying drivers of the cost and opportunities for change, a segmentation of all freight flows of South Africa and areas where costs could improve was done. This was achieved by translating the transportable GDP of South Africa (the primary and secondary sectors of the economy) into detailed freight flows (FDM). A summary of the result that can assist with segmentation is depicted in Fig. 6.

The obvious largest segment that are visible is the R72 billion ( $40 \%$ of the national freight bill) that is spent on the transport of finished goods. These flows resulted in the identification of five overarching freight-flow segments, described in terms of the nature of the commodity and service requirement in Table 1.

Analysis of the total freight flows in the country within this five overarching segments described led to the identification of 15 sub-segments, as illustrated in Fig. 7 (with rail market share depicted as a percentage). The dominant position (and core competence) of the national railroad in the transportation of mining commodities, as well as significant opportunities in other long-distance transportation market spaces, is clear. 
Freight flows with high density over longer distances are well suited to transportation by rail. The obvious gap here is palletised finished goods over long distances, which is hypothesised to achieve sizeable savings on the country's logistics bill.

The results indicate that most long-distance transport of unitisable commodities in South Africa occurs over distances greater than 500 km (Fig. 8), therefore an assumption of distances greater than $500 \mathrm{~km}$ for rail-friendly unitisable commodities was deemed to be conservative, and was adopted.

Rail-friendly freight is, therefore, defined as freight flows between dense origin-destination pairs of 100000 tons per annum (a minimum of a train per week) over distances greater than $500 \mathrm{~km}$. The portion of this freight that is suitable for intermodal transport was subsequently identified.

\section{Identification of intermodal-friendly freight}

According to Brown and Hatch (2002:7), 'rail intermodal's economic value and contribution to the economy resides primarily in long-haul corridors'. They highlight typical freight, mostly fast-moving consumer goods (FMCG). These are products that are sold quickly and are generally consumed on a regular basis, as opposed to durable goods such as kitchen appliances, which are replaced over a period of years. FMCG product categories comprise food and dairy products, pharmaceuticals, consumer electronics, packaged food products, household products, beverages, and the like.

The key driver of density (one of the rail's economic fundamentals, described previously) is the unitisation of cargo. This requires a large storage footprint (e.g., iron ore is stockpiled and containers are stacked while goods within containers are palletised). Distribution centre to distribution centre (DC-to-DC) traffic for redistribution is naturally densified around a few corridors, but has no intermodal potential if it cannot be unitised (through palletisation) and 'connected' from shelf to shelf between these DCs. For the purposes of isolating intermodalfriendly transport from rail-friendly freight flows, the concept of 'unitisable' was therefore narrowed to 'palletisable' in order to ensure that only freight that can be easily packed on pallets and stacked in containers was identified. In order to identify freight that could be described as 'palletisable', three workshops were conducted with industry experts, and the commodities from the FDM were classified into two groups: 'palletisable' and 'nonpalletisable'. This classification is reflected in Table 2.

Finally, the concept of terminal density was added as a special consideration for intermodalfriendly transport. Dense terminals lead to the standardisation of equipment and processes, which drives down costs (Kreutzberger 2008) and reduce the distance at which intermodal transport becomes more cost effective than road-only transport. In this case, two types of flows were considered: long-distance between metropolitan areas (as 'low-hanging fruit', or traffic that can switch easily) and those from large manufacturing installations in rural areas to metropolitan areas.

\section{Findings and discussion}

Initial research based on the 2009 data identified 192 million tons (or 100 billion tonkm) of corridor freight (Havenga, Simpson, Fourie, \& De Bod, 2011). The research methodology on 
which these figures were based has since been greatly improved and the 2009 data was updated in conjunction with the 2010 data that was researched based on the same new methodology. The new calculation (Table 3 ) indicates that $65 \%$ of potential intermodal freight shipped moves between metropoles, while $51 \%$ of potential intermodal freight shipped moves on the Gauteng-Cape Town corridor (Cape corridor) and the GautengKwaZulu-Natal corridor (Natal corridor) alone.

Potential intermodal tonkm increased more than the potential intermodal tons, indicating increased average distances. This further strengthens the argument for super terminals in Gauteng, Durban and Cape Town to capture densified corridor freight between these centres.

The Cape and the Natal corridor offer a sizeable market for intermodal freight (relative to the current railway turnover and volumes), contributing a total of 22.9 million tons and 12.8 billion tonkm. Currently the railway moves 9 million tons of general cargo (non intermodal) on these two corridors. This potential will increase rail freight with $248 \%$ (a market share improvement from $11 \%$ to $39 \%$ for tons on these two corridors). The proposed domestic intermodal solution will achieve national objectives, lower the cost of transport (also through returns to density), alleviate congestion and reduce emissions.

The potential cost reduction achieved through an intermodal solution is attributable to a shift on the Harris curve due to an increase in density. Fig. 9 shows that potential intermodal freight has a density of 1.0 million ton $\mathrm{km} /$ routekm, while the Cape and Natal rail corridors have a slightly higher density at 1.2 million ton $\mathrm{km} /$ routekm. If the potential intermodal freight on these two corridors was to be shifted to rail, the density would increase to 4.8 million tonkm, a sizeable move down the Harris curve.

Table 4 illustrates the sizable cost saving potential of the proposed domestic intermodal solution, being a R3.5 billion alone on two intermodal services between 3 terminals.

The rail service required to offer this service is relatively simple, fits rails' unique capabilities perfectly and makes a sizable contribution to alleviate the capital intensive nature of the railway.

Table 5 illustrates the cost savings when externality charges are taken into consideration for both the current road only solution and the proposed intermodal solution. The R3.5 billion saving for the two services alone increases from R3.5 billion to R4.8 billion when externalities are considered, which is a decrease of $64 \%$.

It is expected that most externalities will eventually be charged, which makes it important to consider these charges.

The net current value of a substantial increase over the next decade will lead to an even stronger business case for this move to intermodal solutions. The worst case scenario, i.e., an oil price of $\$ 500$ per barrel by 2030 will increase the cost of all potential intermodal freight in South Africa to R26.5 billion in current terms (including externality costs). This means that a move to a comprehensive domestic intermodal solution, which will arguably take a long time to implement, could save the country more than R10 billion in current terms by 2030. 
The introduction of a carbon tax will lead to a much greater focus on emission reduction to reduce logistics costs and carbon footprint. First-World markets already discriminate against high carbon footprint commodities. Clavin (2010) analysed ethical consumerism in the UK from 2007 to 2009 in various economic sectors. The highest growth in ethical product consumption was reported in the food and drink sector (27\%) and the personal products sector $(29 \%)$ - the target industries for intermodal solutions proposed in this article. It will be important for freight owners to demonstrate a lower carbon footprint in order to remain competitive. Fig. 10 depicts the potential reduction in tonnage of $\mathrm{CO}_{2}$ emissions if an intermodal solution is implemented in South Africa.

\section{Conclusion and implications for managerial practice}

The challenges in developing and implementing successful domestic intermodal freight solutions are manifold, as highlighted by international experiences, and should be approached realistically. However, as illustrated, the potential benefits of domestic intermodal solutions to the South African economy are clear - significant cost and emissions reductions in an uncertain energy- and carbon-offset world. The economic realities of the future and increased demand for freight transport also leave players little choice but to galvanise solutions in this area. Stone's (2008: 246) view that domestic intermodal 'will be a significant part of the expectations of a new invigorated rail freight activity' is therefore supported by the findings presented in this article.

The stakeholders in the potential domestic intermodal freight market in South Africa are highly concentrated. There are three core groups: the railway, logistics service providers, and shippers or freight owners, with the market concentration spread over a limited number of large freight owners. A collaborative approach by these role players is a realistic possibility and should be attempted. A more in-depth feasibility study is required to design specific services in this regard.

The research in this paper confirms that proper freight flow segmentation could identify new and interesting market niches for rail. Applying costs to the various segments can enable business case formulation for these segments and illustrate possible savings through alternative transport solutions.

Tables

Table 1.

Description of the overarching freight-flow segments.

\begin{tabular}{||l|l||}
\hline Pit to port & $\begin{array}{l}\text { Bulk export mining; rail-only transport with high density; long } \\
\text { distances; }<500 \text { origins; and } 10 \text { destination ports }\end{array}$ \\
\hline \hline Pit to plant & $\begin{array}{l}\text { Bulk mineral mining for domestic beneficiation; stockpile to } \\
\text { manufacturing plant; more complex flows; }<500 \text { origins; }<7500 \\
\text { destinations; long distances of } 400-900 \mathrm{~km}\end{array}$ \\
\hline $\begin{array}{l}\text { Plant to } \\
\text { plant/DC }\end{array}$ & $\begin{array}{l}\text { Heavy break bulk requiring specialised wagons; plant to plant, or plant } \\
\text { to DC; high density; multiple origins }(<7500) \text { with few destinations }\end{array}$ \\
\hline
\end{tabular}




\begin{tabular}{|c|c|}
\hline & $\begin{array}{l}(250 \text { DCs }) ; \text { transport distances nationally }>500 \mathrm{~km} \text { and within } \\
\text { metropoles }<100 \mathrm{~km}\end{array}$ \\
\hline $\begin{array}{l}\text { Finished } \\
\text { goods: DC- } \\
\text { DC }\end{array}$ & $\begin{array}{l}\text { Finished goods; palletised; complex supply chain management } \\
\text { requirements but few origin-destination pairs (between DCs); high } \\
\text { density; transport distances nationally }>500 \mathrm{~km} \text { and within } \\
\text { metropoles }<100 \mathrm{~km}\end{array}$ \\
\hline \multirow{3}{*}{ Rural } & $\begin{array}{l}\text { Agricultural extraction - to cities or production centres; low density; } \\
\text { many origin-destination pairs; transport distances }<500 \mathrm{~km}\end{array}$ \\
\hline & $\begin{array}{l}\text { Agricultural manufacturing delivery - from cities/production centres } \\
\text { to farms and rural areas; low density; many origin-destination pairs; } \\
\text { transport distances, }<500 \mathrm{~km}\end{array}$ \\
\hline & Rural interchanges - between farming areas; low density; seasonal \\
\hline
\end{tabular}

DC: distribution centre.

Table 2.

Classification of palletisable versus non-palletisable final consumption products.

\begin{tabular}{||l|l|}
\hline \multicolumn{1}{|c|}{ Palletisable FMCG } & \multicolumn{1}{c|}{ Non-palletisable FMCG } \\
\hline \hline Food and food processing & $\bullet$ Automotive \\
\hline \hline Beverages & $\bullet$ Electrical machinery \\
\hline \hline$\bullet$ Tobacco products & $\bullet$ Furniture \\
\hline$\bullet$ Pharmaceuticals and toiletries & $\bullet$ Metal products excluding machinery \\
\hline$\bullet \bullet$ Motor vehicle parts and accessories & $\bullet$ Transport equipment \\
\hline$\bullet$ Other chemicals & \\
\hline$\bullet$ Non-metallic mineral products & \\
\hline$\bullet$ Bricks & \\
\hline$\bullet \bullet$ Non-ferrous metal basic industries & \\
\hline$\bullet-$ Machinery and equipment & \\
\hline$\bullet$ Textiles and clothing & \\
\hline \hline$\bullet$ Printing and publishing & \\
\hline$\bullet$ Other manufacturing industries & \\
\hline \hline$\bullet$ Rubber products \\
\hline
\end{tabular}

Table 3.

Intermodal volume potential.

\begin{tabular}{||l|l|l|l||}
\hline \multicolumn{1}{|l|}{} & $\mathbf{2 0 0 9}$ & $\mathbf{2 0 1 0}$ & Increase \% \\
\hline \hline Potential intermodal & \multicolumn{2}{l||}{} \\
\hline Tons (million) & 54.1 & 45.0 & $-17 \%$ \\
\hline \hline Tonkm (billion) & 29.5 & 31.4 & $6 \%$ \\
\hline \hline
\end{tabular}




\begin{tabular}{|c|c|c|c|}
\hline & 2009 & 2010 & Increase \% \\
\hline \multicolumn{4}{|c|}{ Potential intermodal between all metropoles } \\
\hline Tons (million) & 24.5 & 29.2 & $19 \%$ \\
\hline Tonkm (billion) & 11.5 & 16.4 & $43 \%$ \\
\hline \multicolumn{4}{|c|}{ Potential intermodal between 3 metropoles only } \\
\hline Tons (million) & 16.1 & 22.9 & $43 \%$ \\
\hline Tonkm (billion) & 9.5 & 12.8 & $34 \%$ \\
\hline
\end{tabular}

Table 4.

Cost saving potential.

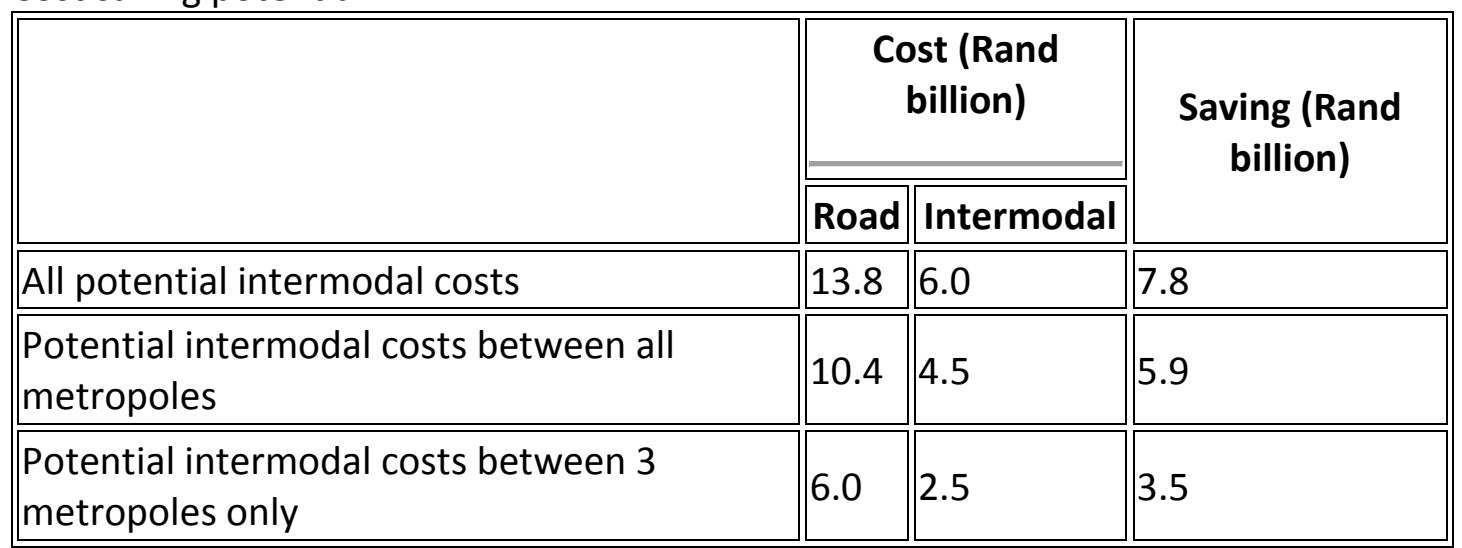

Table 5.

Cost saving potential with externality costs included.

\begin{tabular}{|c|c|c|c|}
\hline & \multicolumn{2}{|c|}{$\begin{array}{l}\text { Cost (Rand } \\
\text { billion) }\end{array}$} & \multirow[t]{2}{*}{$\begin{array}{l}\text { Saving (Rand } \\
\text { billion) }\end{array}$} \\
\hline & Road & Intermodal & \\
\hline All potential intermodal costs & 17.3 & 6.3 & 11.0 \\
\hline $\begin{array}{l}\text { Potential intermodal costs between all } \\
\text { metropoles }\end{array}$ & $\mid 13.6$ & 4.8 & 8.8 \\
\hline $\begin{array}{l}\text { Potential intermodal costs between } 3 \\
\text { metropoles only }\end{array}$ & 7.5 & | 2.7 & 4.8 \\
\hline
\end{tabular}


Figures

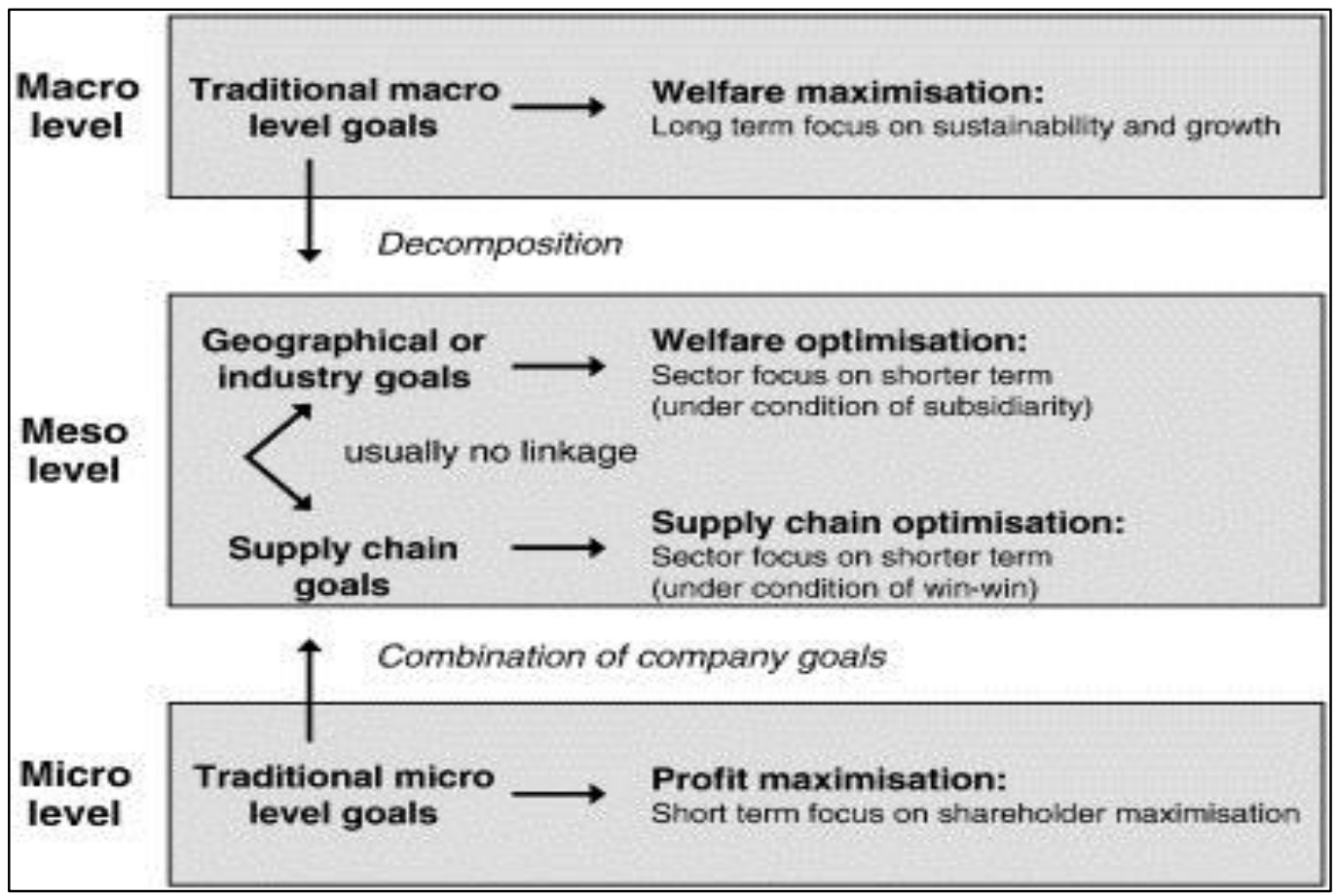

Fig. 1 Demkes and Tavasszy's description of micro, meso and macro indicators (2000).

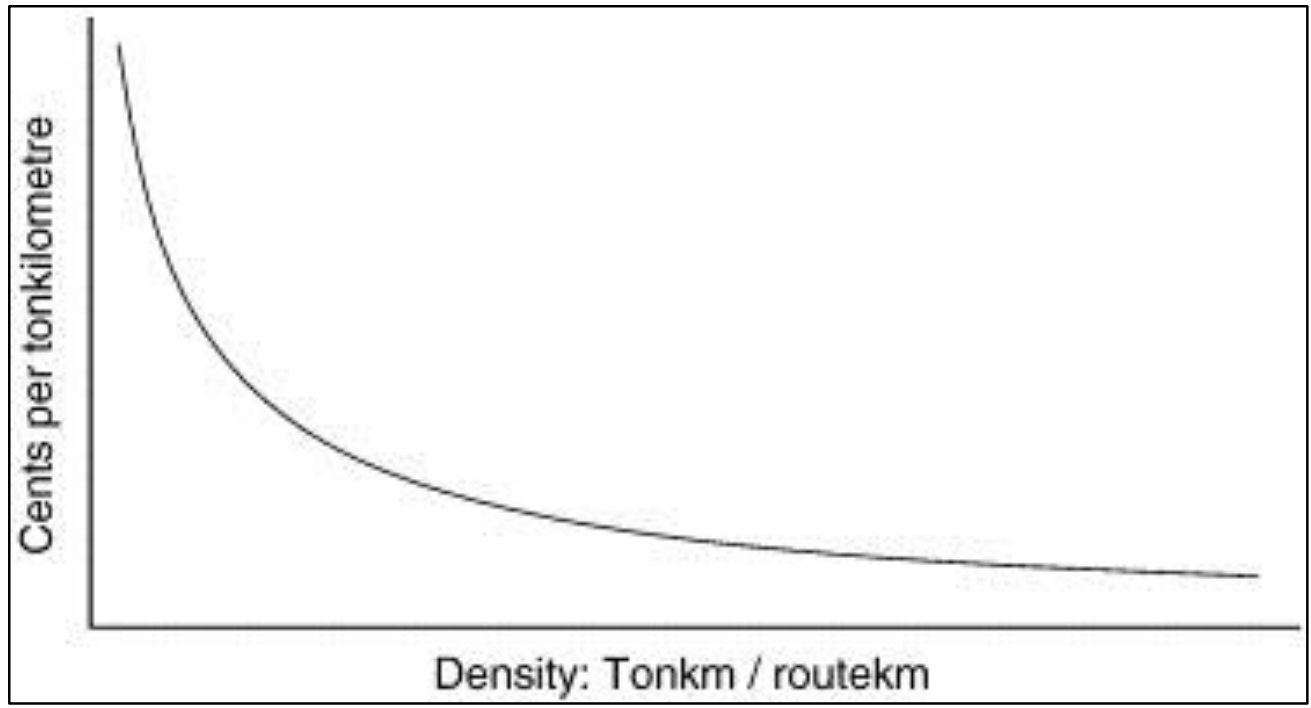

Fig. 2 The economics of rail density.

Adapted from Harris, 1977. 


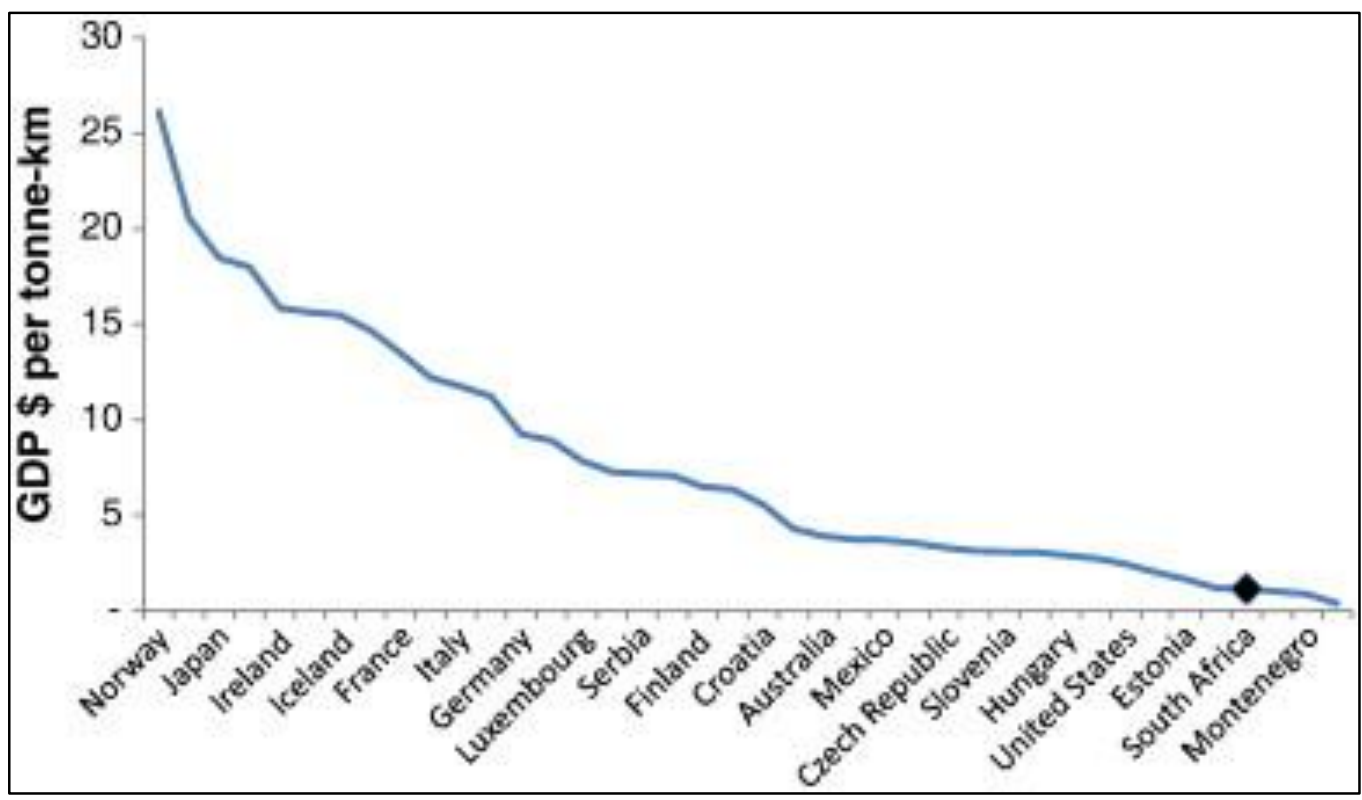

Fig. 3 Contribution to GDP per ton-kilometre (\$) - global comparison (Bambulyak and Frantzen, 2007; OECD, 2010; and US DOT (United States Department of Transport), 2007).

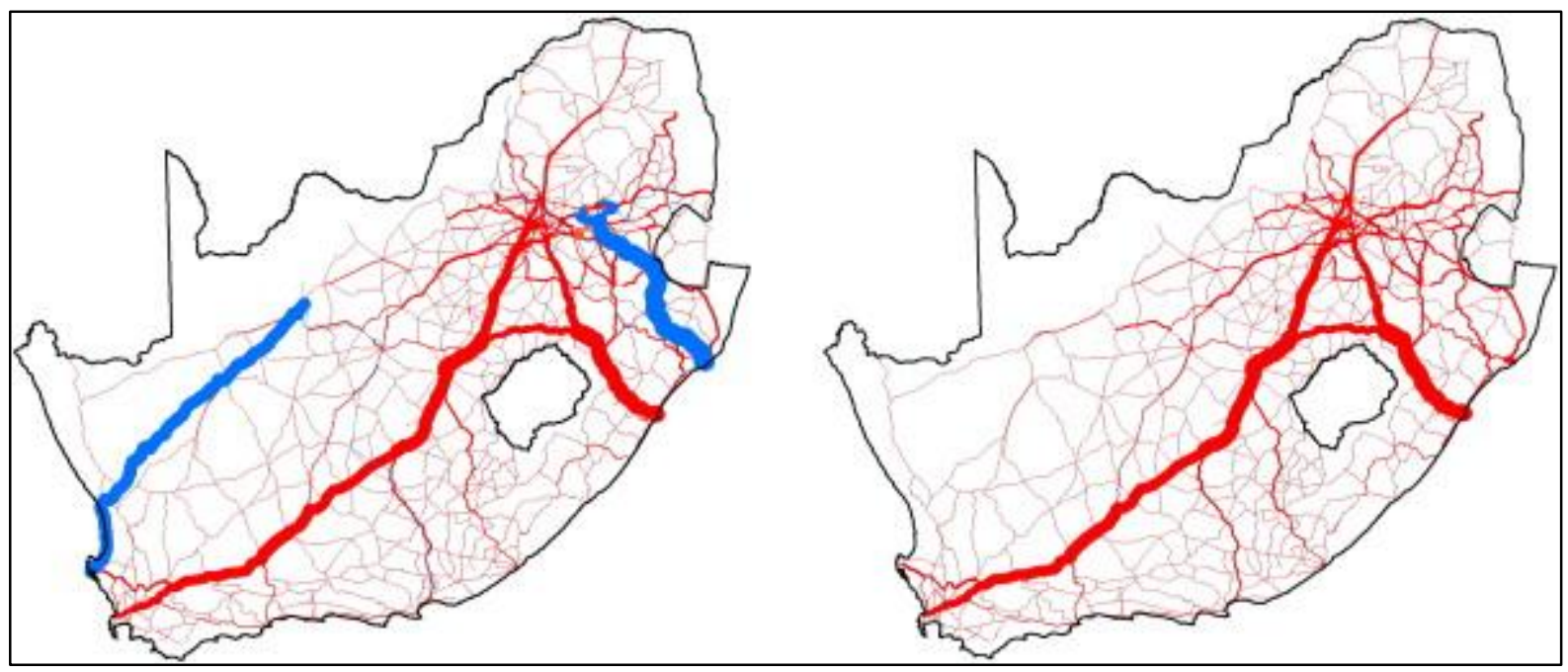

Fig. 4 Freight flows in South Africa. 


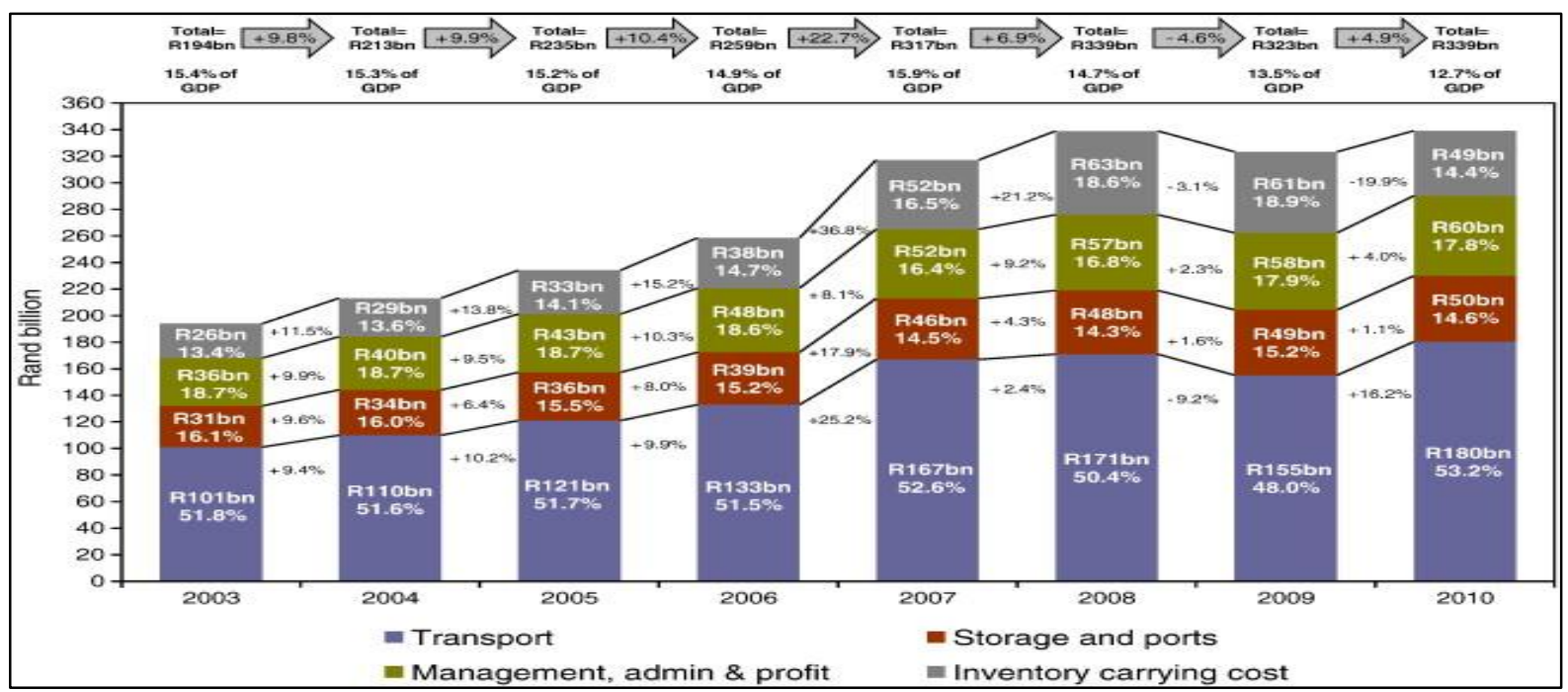

Fig. 5 South Africa's logistics cost stack elements (Simpson \& Havenga).

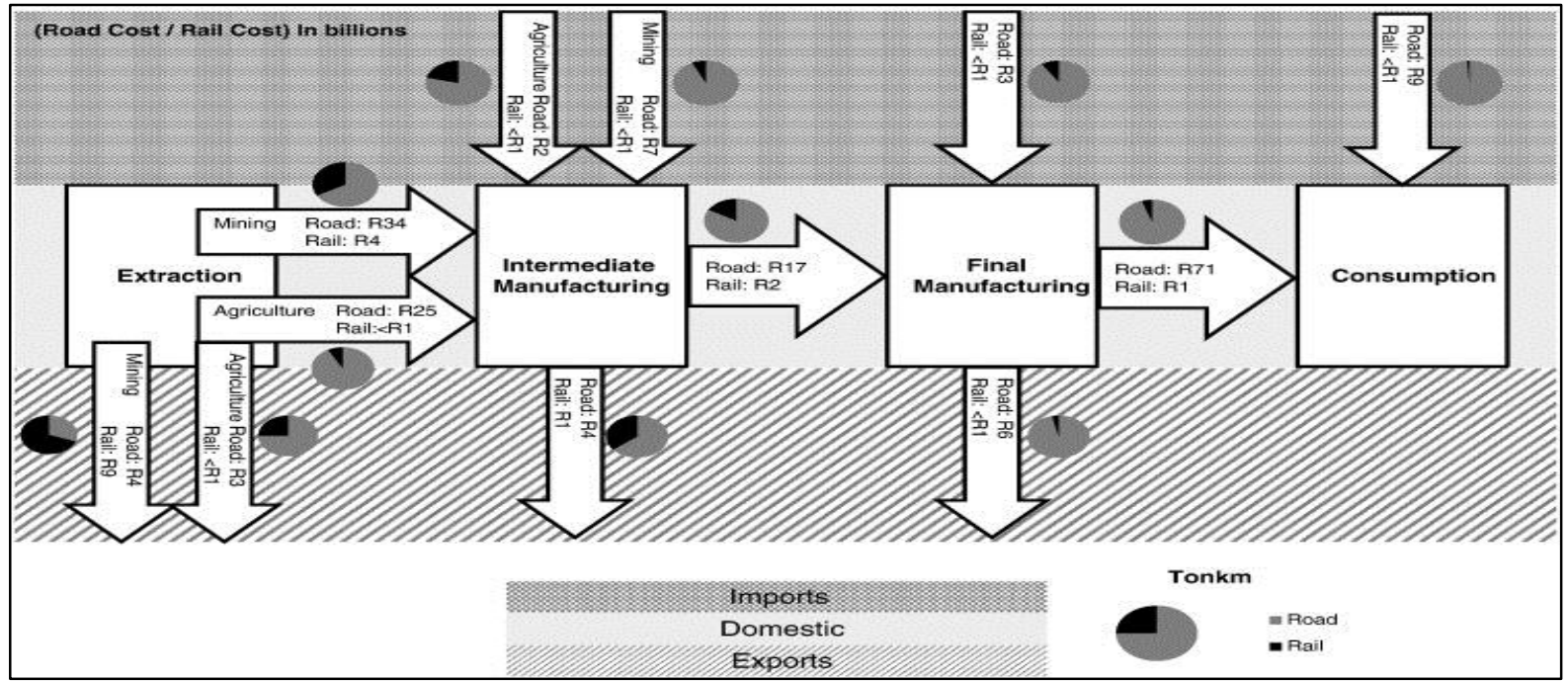

Fig. 6 Basic economic structure and resultant logistics requirements with South Africa's freight flow ( $R=$ Rand, i.e., the cost per mode to deliver the required transport solution). 


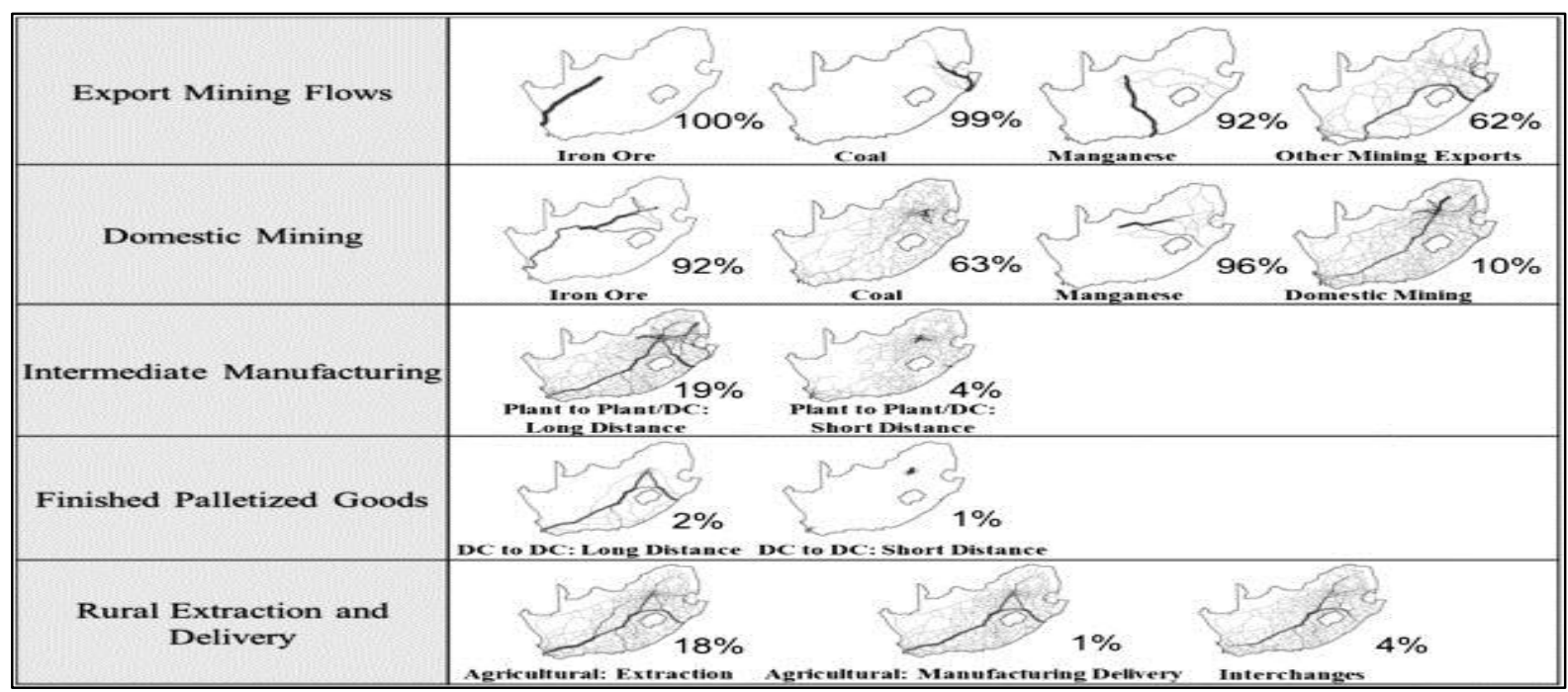

Fig. 7 Total freight flows per sub-segment in tonnage terms; rail share in percentage (FDM).

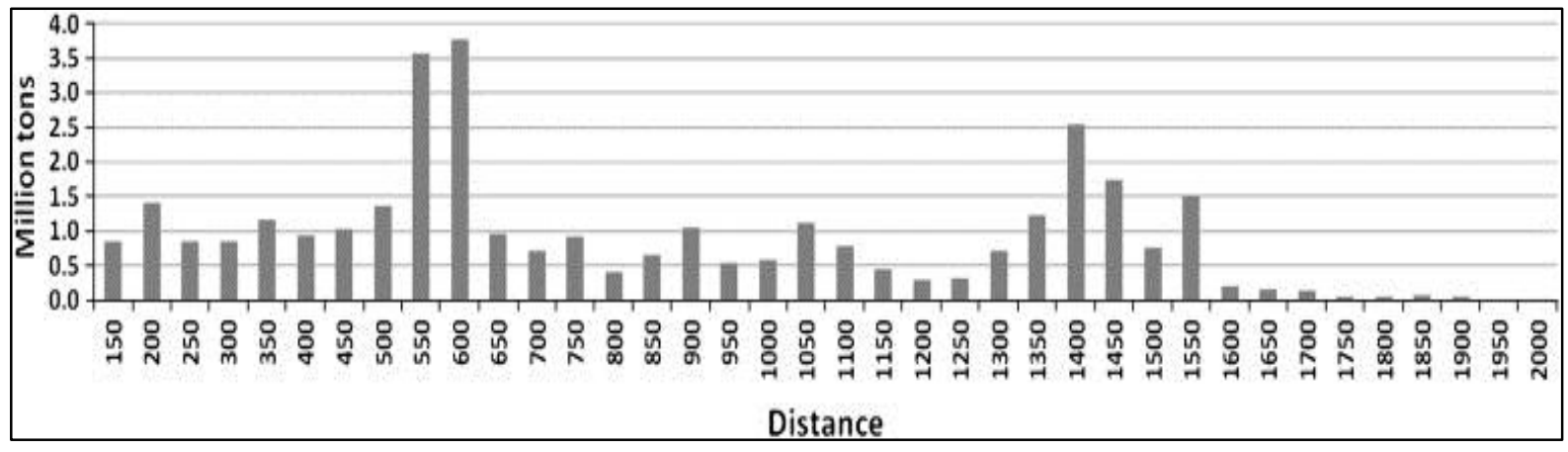

Fig. 8 Transport distances of unitisable commodities $>150 \mathrm{~km}$ (FDM). 


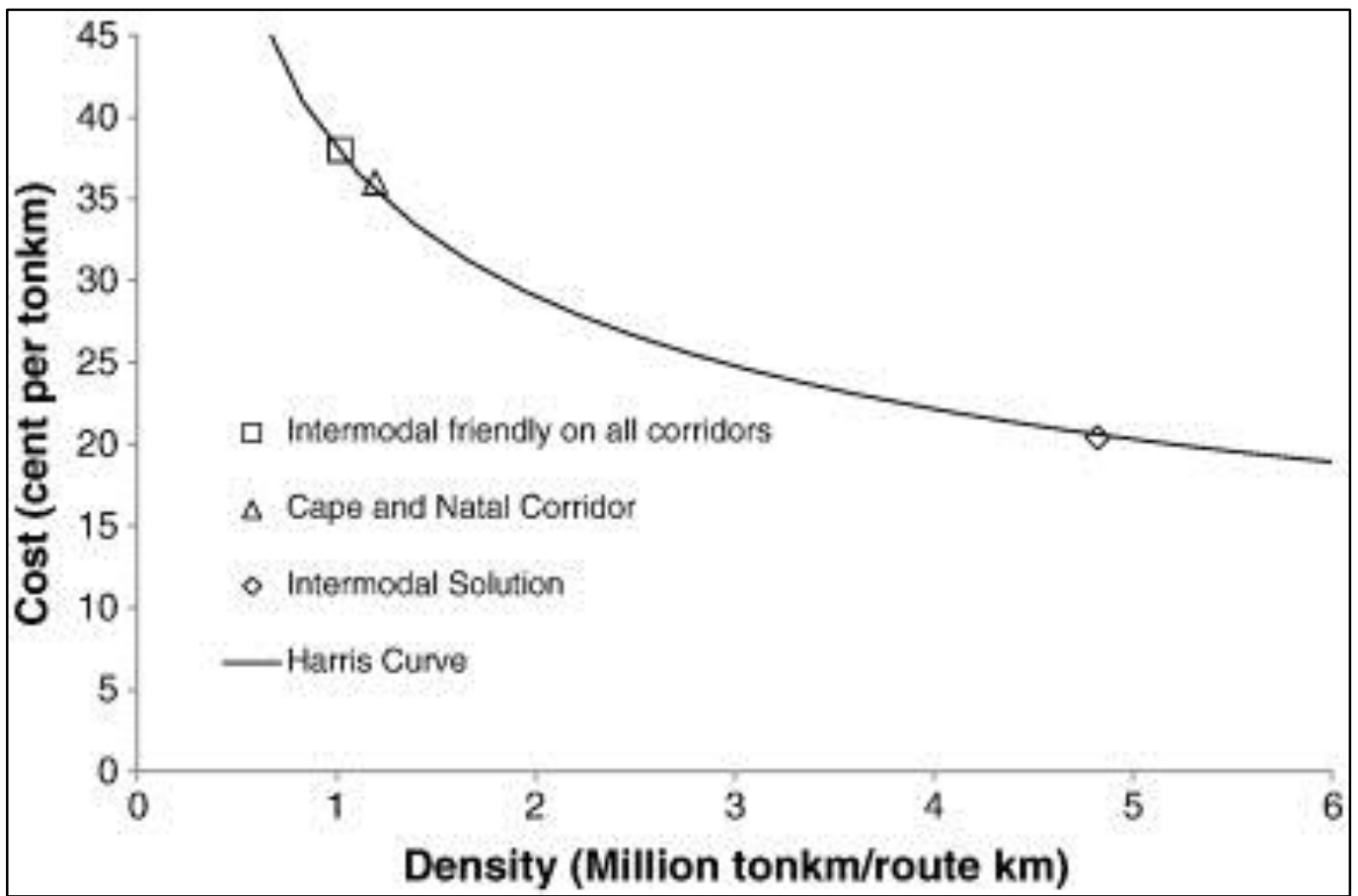

Fig. 9 Intermodal density change on the Harris curve due to density-driven savings.

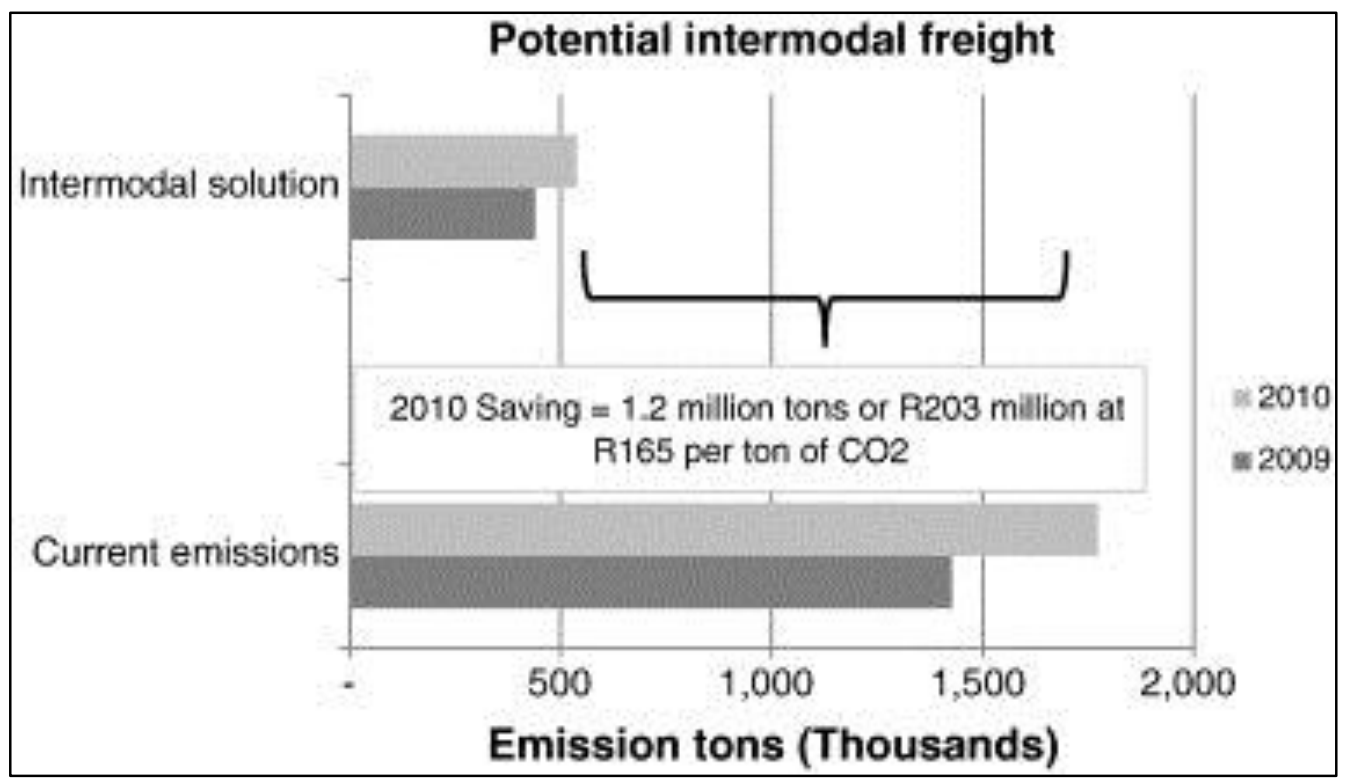

Fig.10 Reduction in tonnage $\mathrm{CO}_{2}$ emissions due to an intermodal solution on the Cape and the Natal corridors. 


\section{References}

Association of American Railroads, 2011 Association of American Railroads Rail intermodal keeps America moving Available at: http://www.aar.org/Economy/ /media/aar/Background-Papers/RailIntermodal.ashx (2011) (accessed 13 June 2011)

Bambulyak and Frantzen, 2007 A. Bambulyak, B. Frantzen Oil transport from the Russian part of Barents region: Status as per January 2007 The Norwegian Barents Secretariat and Akvaplan-niva, Norway (2007)

Berwick, 2001 M. Berwick North Dakota strategic freight analysis: Item I. Intermodal highway/rail/container transportation and North Dakota North Dakota State University, Fargo (2001)

Brown and Hatch, 2002 T.R. Brown, A.B. Hatch The value of rail intermodal to the US economy. The American Association of State Highway and Transportation Officials: Special committee on intermodal transportation and economic expansion Available from: http://intermodal.transportation.org/Documents/brown.pdf (2002) (accessed 4 July 2011)

Case, 2009 R. Case The complex future of the North American rail network Transport and LogisticsOliver Wyman, Toronto (2009, Spring)

Clavin, 2010 B. Clavin Ethical consumerism report 2010: Ethical shopping through the downturn The Co-operative Bank, Manchester (2010)

Creamer, 2011 T. Creamer Transnet opens door to private participation in big rail, ports projects Engineering news (2011, June 17)

De Witt and Clinger, 1999 W. De Witt, J. Clinger Intermodal freight transportation Committee on Intermodal Freight TransportUS Transportation Research Board (1999) (Available from: http://onlinepubs.trb.org/onlinepubs/millennium/00061.pdf (accessed 21 June 2011))

Demkes and Tavasszy, 2000 R. Demkes, L.A. Tavasszy Benchmarking infrastructure and logistics services across Europe, Asia-Pacific and North America Paper presented at IMRL 2000, third international meeting for research in logistics, Trois-Rivieres, 9-11 May (2000)

DoT (National Department of Transport, South Africa), 1998 DoT (National Department of Transport, South Africa) Moving South Africa: A transport strategy for 2020. Chapter 9: Strategy recommendations: Freight customers Department of Transport, Pretoria (1998)

DoT (National Department of Transport, South Africa), 2005 DoT (National Department of Transport, South Africa) National freight logistics strategy Department of Transport, Pretoria (2005)

DoT (National Department of Transport, South Africa), 2011 DoT (National Department of Transport, South Africa) Road freight strategy for South Africa: Final draft Department of Transport, Pretoria (2011)

EIRAC (European Intermodal Research Advisory Council), 2005 EIRAC (European Intermodal Research Advisory Council) Strategic intermodal research agenda 2020 European Intermodal Research Advisory Council, Brussels (2005)

European Commission, 1997 European Commission Communication from the Commission to the European Parliament and the Council: Intermodality and intermodal freight transport in the European Union (1997) Available from: 


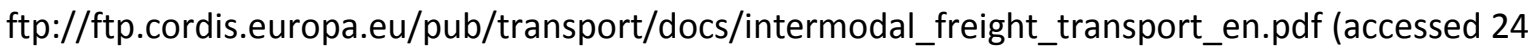
November 2012)

European Commission, 2008 European Commission ICT and e-business impact in the transport and logistics services industry Study report no. 05/2008, European Commission, DG Enterprise \& Industry, Brussels (2008)

European Commission, 2011 European Commission Marco Polo - New ways to a green horizon Available from: http://ec.europa.eu/transport/marcopolo/ (2011) (accessed 21 June 2011)

Fantazzini et al., 2011 D. Fantazzini, M. Höök, A. Angelantoni Global oil risks in the early 21st century Energy Policy, 39 (2011), pp. 7865-7873

Grant et al., 2006 D.B. Grant, D.M. Lambert, J.R. Stock, L.M. Ellram Fundamentals of logistics management (European edition)McGraw-Hill, Maidenhead (2006)

Grove, 2005 J. Grove Chief executive's report, Unitrans Limited annual report Unitrans Limited, Johannesburg (2005)

Harris, 1977 R.G. Harris Economies of traffic density in the rail freight industry Bell Journal of Economics, 8 (2) (1977), pp. 556-564

Havenga, 1995 Havenga, J.H. (1995). Intermodal transport within Transnet: A Spoornet perspective. Unpublished research report of the Piggyback Study Group. Johannesburg: Transnet.

Havenga, 2007 Havenga, J.H. (2007). The development and application of a freight transport flow model for South Africa. Unpublished PhD thesis. Stellenbosch University

Havenga, $2010 \mathrm{~J}$ J. Havenga Logistics costs in South Africa - The case for macroeconomic measurement South African Journal of Economics, 78 (4) (2010), pp. 460-478

Havenga, 2011 J.H. Havenga Trade facilitation through logistics performance: The enabling role of national government Journal of Transport and Supply Chain Management, 5 (1) (2011), pp. 123-148

Havenga and Pienaar, 2012 J.H. Havenga, W.J. Pienaar The creation and application of a national freight flow model for South Africa Journal of the South African Institution of Civil Engineering, 54 (1) (2012), pp. 2-13

Havenga, Pienaar and Simpson, 2011 J.H. Havenga, W. Pienaar, Z. Simpson A case for measuring logistics costs on a national level: A South African application Corporate Ownership and Control, 8 (3) (2011), pp. 622-631

Havenga, Simpson, Fourie and De Bod, 2011 J.H. Havenga, Z. Simpson, P.F. Fourie, A. De Bod Sustainable freight transport in South Africa: Domestic intermodal solutions Journal of Transport and Supply Chain Management, 5 (1) (2011), pp. 149-169

Havenga et al., 2010 J.H. Havenga, Z.P. Simpson, J. Van Eeden, P.F. Fourie, I. Hobbs, M. Braun Logistics costs - Volatility, agility and future shock Seventh annual state of logistics survey for South AfricaCSIR, Imperial and Stellenbosch University (2010)

Havenga et al., 2009 J.H. Havenga, J. Van Eeden, Z.P. Simpson The state of logistics in South Africa Sustainable improvements or continued exposure to risk Sixth annual state of logistics survey for South Africa (2009) (Available from: http://www.csir.co.za/sol/docs/6th SoL survey web final.pdf (accessed 4 July 2011)) 
Jammernegg and Reiner, 2007 W. Jammernegg, G. Reiner Performance improvement of supply chain processes by coordinated inventory and capacity management International Journal of Production Economics, 108 (1) (2007), pp. 183-190

Jannic and Reggiani, 2001 M. Jannic, A. Reggiani Integrated transport systems in the European Union: An overview of some recent developments Transport Reviews, 21 (4) (2001), pp. 469-497

Jorgensen, 1999 A.A. Jorgensen Intermodal transport options for international and domestic freight requirements in southern Africa Council of Logistics Management conference. Johannesburg, April (1999)

Jorgensen, 2009 A.A. Jorgensen Transport costs and the relevance of externalities: A discussion paper Africa rail (2009, June 25)

Kolstad, 2009 T. Kolstad Domestic intermodal traffic is the best hope for railroad recovery Available from: http://www.glgroup.com/News/Domestic-intermodal-traffic-is-best-hope-for-railroadrecovery-42619.html (2009) (accessed 23 June 2011)

Kreutzberger, 2008 E. Kreutzberger The impacts of innovative technical concepts for load unit exchange on the design of intermodal freight bundling networks R. Konings, H. Priemus, P. Nijkamp (Eds.), The future of intermodal freight transport, Edward Elgar, Cheltenham (2008)

Laaksonen, 1999 S. Laaksonen Employment and technology: results of recent econometric research J. Lievonen, J.C. Císcar (Eds.), IPTS-ESTO techno-economic analysis report, European Commission (1999, June)

McKenzie, 2011a J. McKenzie SA stresses partnerships, local content as it meets transport investors Engineering news (2011, June 13)

McKenzie, 2011b J. McKenzie Four major SA roads projects presented to potential investors Engineering news (2011, June 14)

McKinnon, 2009 A.C. McKinnon The present and future land requirements of logistical activities Land use policy, 26S (2009), pp. S293-S301

Naidoo, 2011 B. Naidoo Moving freight to rail could offset higher costs due to carbon taxing Engineering news (2011, June 3)

Nemoto et al., 2005 T. Nemoto, M. Browne, J. Visser, J. Castro Intermodal transport and city logistics policies Proceedings of the 4th international conference on city logistics, Langkawi, Malaysia (2005)

OECD, 2010 OECD Trends in the transport sector 1970-2008: Container transport dataset. International Transport Forum OECD (2010) (Available from: http://www.internationaltransportforum.org/statistics/trends/index.html (accessed 4 July 2010))

Peach, 1992 J.D. Peach Intermodal freight transportation: Combined rail-truck service offers public benefits, but challenges remain Report to the Committee on Public Works and Transportation, House of Representatives, United States General Accounting Office, Resources, Community and Economic Development Division, Washington (1992)

Peetermans and Sellnick, 2010 E. Peetermans, O. Sellnick Report on combined transport in Europe International Union of Railways, Paris (2010, December) 
Piecyk and McKinnon, 2007 M. Piecyk, A.C. McKinnon Internalising the external costs of road freight transport in the UK Heriot-Watt University, Edinburgh (2007)

Radetzki, 2002 M. Radetzki Is resource depletion a threat to human progress? Oil and other critical exhaustible materials The Centre for Energy, Petroleum and Mineral Law and Policy - The journal, 10 (2002) (Article 9. Available from:

http://www.dundee.ac.uk/cepmlp/journal/html/vol10/article10-9.html (accessed 21 May 2012))

Roberts, 2003 P.O. Roberts Supply chain management: New directions for developing economies SAIC, World Bank (2003) (Available from: http://logmgt.nkmu.edu.tw/news/articles/SCMNew\%20Direction.pdf (accessed 4 June 2002))

Rodrigue and Browne, 2008 J.P. Rodrigue, M. Browne International maritime freight movements and logistics R.D. Knowles, J. Shaw, I. Docherty (Eds.), Transport geographies: Mobilities, flows and spaces, Blackwell, London (2008)

SA National Treasury, 2010 SA National Treasury Discussion paper for public comment - Reducing greenhouse gas emissions: The carbon tax option (2010, December)

Schwartz et al., 2009 J. Schwartz, J.L. Guasch, G. Wilmsmeier Logistics, transport and food prices in LAC: Policy guidance for improving efficiency and reducing costs LCSSD Economics Unit, the World Bank and the Inter-American Development Bank, August, no. 2 (2009)

Silborn, $2008 \mathrm{H}$. Silborn Measures promoting intermodal transport as an alternative to pure road transport - Proceedings of the international conference on heavy vehicles, Paris, 19-22 May (2008)

Simchi-Levi, 2011 D. Simchi-Levi How volatile oil prices will rock the supply chain CSCMP's supply chain quarterly, quarter 4/2011 (2011)

Simpson and Havenga, 2011 Z. Simpson, J.H. Havenga Logistics costs - Lower relative costs, higher risks Eighth annual state of logistics survey for South AfricaCSIR, Imperial and Stellenbosch University (2011)

Sommar and Woxenius, 2007 R. Sommar, J. Woxenius Time perspectives on intermodal transport of consolidated cargo European Journal of Transport and Infrastructure Research, 7 (2) (2007), pp. 163182

Stock and Lambert, 2001 J.R. Stock, D.M. Lambert Strategic logistics management (4th ed.)McGrawHill, Boston (2001)

Stone, 2008 B. Stone Critical success factors: Interconnectivity and interoperability. The future of intermodal freight transport Edward Elgar, Cheltenham (2008)

The Presidency, 2011 The Presidency Diagnostic: Transport infrastructure - Roads, rail, ports and air National Planning Commission (2011, June 8) (Available from:

http://www.npconline.co.za/pebble.asp?relid=184 (accessed 4 July 2011))

US DOT (United States Department of Transport), 2007 US DOT (United States Department of Transport) 1990-2007 estimates US DOT, Washington, DC (2007)

Van Eeden and Havenga, 2010 J. Van Eeden, J.H. Havenga Identification of key target markets for intermodal freight transport solutions in South Africa Journal of Transport and Supply Chain Management (2010, November), pp. 255-267 
Wilson, 2010 R. Wilson Twenty-first annual state of logistics report: The great freight recession Council of Supply Chain Management Professionals, Washington, DC (2010)

Winkler and Marquard, $2011 \mathrm{H}$. Winkler, A. Marquard Analysis of the economic implications of a carbon tax Journal of Energy in Southern Africa, 22 (1) (2011), pp. 55-68

Wisner et al., 2005 J.D. Wisner, G.K. Leong, K. Tan Principles of supply chain management: A balanced approach Thomson South-Western, Mason, Ohio (2005)

Woodburn, 2008 A. Woodburn Intermodal freight in Britain: A terminal problem? Planning, Practice and Research, 23 (3) (2008, August)

Woodburn, 2012 A. Woodburn Intermodal rail freight activity in Britain: Where has the growth come from? Research in Transportation Business \& Management (2012) http://dx.doi.org/10.1016/j.rtbm.2012.09.001

Woodburn and Piotrowska, 2012 A. Woodburn, M. Piotrowska The addressable freight markets for rail and water: A review of the British situation Logistics research network - Proceedings of the 17th conference, Cranfield, 7-9 September (2012)

Woodburn and Whiteing, 2010 A. Woodburn, A. Whiteing Transferring freight to 'greener' transport modes A. McKinnon, S. Cullinane, M. Browne, A. Whiteing (Eds.), Green logistics: Improving the environmental sustainability of logistics, Kogan Page, London (2010)

World Bank, 2010 World Bank How to decrease freight logistics costs in Brazil Report no. 46885-BR (2010)

World Bank, 2012 World Bank Merchandise trade (\% of GDP) Available at http://data.worldbank.org/indicator/TG.VAL.TOTL.GD.ZS (2012) Accessed 31 October, 2012

Woxenius, $2007 \mathrm{~J}$. Woxenius Alternative transport network designs and their implications for intermodal transhipment technologies European Transport, 35 (1) (2007), pp. 27-45

Woxenius and Bärthel, $2008 \mathrm{~J}$. Woxenius, F. Bärthel Intermodal road-rail transport in the European Union R. Konings, H. Priemus, P. Nijkamp (Eds.), The future of intermodal freight transport, Edward Elgar, Cheltenham (2008)

Yevdokimov, 2000 Y.V. Yevdokimov Measuring economic benefits of intermodal transportation Transportation Law Journal, 27 (3) (2000), pp. 439-452 